e-ISSN: 2622-3597. Available online at https://jurnal.umj.ac.id/index.php/ELIF

Peer-review under responsibility of Muhammadiyah University of Jakarta, Indonesia

\title{
ELT Comparison: Increasing Students Speaking Ability in Indonesia, South Korea, Russia, and Poland
}

\author{
Tresna Nur Andini'1), Lee Ye Eun ${ }^{2}$, Alina Khramova3), Alicja Żok ${ }^{4)}$ \\ 1) Universitas Muhammadiyah Jakarta, South Tangerang, Banten, Indonesia \\ 2) Kwangwoon University, Seoul, South Korea \\ 3)Kazan National Research Technology University, Kazan, Russia \\ 4)Poznan University of Medical Sciences, Poznan, Poland \\ 1)tresnanur5@gmail.com, 2)dpdms7571@naver.com, \\ 3)hramova-alinka-94@yandex.ru, 4)faplesslovess@gmail.com
}

\begin{abstract}
English as a global language facilitates the people to communicate with each other despite different lingua-cultures or accent. Communication will be something important to build the socio condition of civilians in every single country. This background of research leads to get to know about English Language Teaching (ELT) to the people whose first language is not English. Each country in Asia or Europe whose English is not their first language has its differences in teaching and learning about English. The four basic things of English, such as reading, writing, and speaking will be the challenges that they need to be faced. According to the basics of four skills, speaking is the hardest one for most non-native speakers. Therefore, the teachers need to have particular ways to teach about speaking to increase students' skill ability in EFL countries. This research is aimed to show the differences and comparisons among Indonesian and South Korea as the representatives of Asia, also Russia and Poland as the representatives of Europe whose first language is not English. This purpose means that people can distinguish among different types in each country for teaching and learning English, moreover for speaking skills.
\end{abstract}

Keywords: English Language Teaching, Speaking Skill, English Educational Students

Citation APA Style: Andini, T. N., Eun, L. Y., Khramova, A., \& Żok, A. (2020). ELT Comparison: Increasing Students Speaking Ability in Indonesia, South Korea, Russia, and Poland. English Language in Focus (ELIF), 2(2), 131-140.

\section{INTRODUCTION}

$\mathrm{E}$ nglish has become an international language for all countries in the world. English is not just a language, but more like a bridge for communication and cross-culture among all cultures in the world. Therefore, the function of English for educational purposes is really important and English is the ability that must be mastered by students (Hadi \& Izzah, 2019). The ability of language for communication in the international world is what requires the students to master English, not only in writing but also in speaking. There are four basic skills in English, those are 
writing, listening, reading, and speaking. The learning of speaking cannot be separated from the language so that speaking should make the students master this aspect (Rizqiningsih \& Hadi, 2019). But, the most important is speaking because of how fluent people speak in English, then how easy to deliver the message through oral and how easy to communicate with people from all around the world. Speaking of oral practice often finds many struggles to be taught and learned. The problem of practicing oral in English is something common that is usually found in EFL countries. Mostly the reason why do people assume it as the difficulty to be learned is that English is seen as a foreign and difficult language. It is also influenced by the effect of teaching and learning English in oral practice that we usually know as speaking skills.

Chaney in Kayi (2006, p. 1) stated that speaking is the process of building and sharing meaning through the use of verbal and non-verbal symbols in a variety of contexts. Speaking is a crucial part of language learning. It needs the speakers to produce the target language in the spoken form. Besides, Qureshi (2012) said that speaking skill has some roles and importance, for examples like language is a tool for communication, for a smooth running of any system, to express one's thoughts, opinions, and feelings, in the form of words put together in a meaningful way, and to gain the attention of the audience.

Based on those functions, we can conclude that language is an important tool of communication that can be a bridge for crossing culture among the countries. Besides, based on Richards
(2008, p. 19), the mastery of speaking skills in English is a priority for many second languages or foreign language learners. Consequently, learners often evaluate their success in language learning as well as the effectiveness of their English course based on how much they feel they have improved in their spoken language proficiency.

Supporting the statements above, Harmer (2015, p. 269) classified two elements that are necessary for spoken language. The first is a language feature that had been identified as follows. a) connected speech. Is the modification in sound production or utterances, such as assimilation, omission, addition and weakened? b) expressive devices. Native English speaker changes the pitch and stress of particular parts of utterances, vary volume and speed, and show by other physical and nonverbal means to show how they are feeling. c) lexis and grammar. It is related to the ability to use some of the common lexical phrases, such as agreeing and disagreeing, expressing surprise, shock or approval. e) negotiation language. It is the ability to earn the benefits of the negotiator language we use to seek clarification and show the structure of what we are saying.

Many students take an additional lesson to develop their speaking ability since they have the mindset that their goals will be reached easily in a better way just if they can master English in speaking or oral practical. But, the result of learning to speak in English is not determined by how hard is the effort from the students, but also how great the methods that are used in teaching activity. Therefore, teaching English 
should be suitable for its function. There are many ways or lectures to teach speaking in English. Ur (1996, p. 103) also delivers her idea about it, in teaching speaking skill, the emphasis will usually be firmly on fluency. What we are interested in here and what is emphasized is the development of learners' facility in receiving and conveying messages, with a corresponding lowering of emphasis on accuracy. Furthermore, to asses speaking accuracy well as what the function of itself, Brown (2004, p. 140) points out that speaking is a kind of productive skill that can be directly and empirically observed. However, assessing speaking is challenging because there are so many factors that influence teachers' impressions on how well someone can speak a language.

To make sure that teaching English in the function of speaking or oral can be reached well, then the teachers should consider the effect of teaching and learning to students' psychology. As Harmer (2015, pp. 101$102)$ every said that additionally proposes that assessing speaking performance should be represented through praise or comment. Therefore, the teacher should find an appropriate way to appreciate the students' effort, not just to give the motivation, but to also make the learning and teaching activity becomes fun and easier. The teacher should find media and methods to increase creativity to build students' selfesteem, students' courage and also students' creativity. These ways will be more efficient and effective.

The teaching of speaking in each EFL country has the same problem and difficulty. All those things should be considered from what methods and ways which are used by the teacher in teaching and learning activity. The difficulties that are mostly found can be caused by students' adaptation in learning English, moreover to speak English, and other ones like the methods are not appropriate to be used in the class. Many factors can be seen and identified, therefore we should distinguish and get to know the differences of teaching speaking in each EFL country. Therefore, the writer decided to take samples of four EFL countries to compare their differences in teaching English for speaking only. Those are Indonesia, South Korea, Russia, and Poland.

Indonesia is an EFL country which is located in South-East Asia. As a multicultural country, Indonesia becomes a country that has many languages, races, and cultures. All those things became the reasons why many Indonesians assumed that English is a difficult language to be learned. These problems are also influenced by educational development that has not been average in all Indonesia's area, moreover in the border area. There are many considerations and factors to be identified to develop, increase, and improve the students' speaking ability through English language teaching. It is not just about what is the method or the quality of the teacher, but also about how the average is English in all Indonesia's area and how the government can be sure to facilitate the teaching and learning activity.

South Korea is an EFL country which is located in East Asia and becomes one of the superpower 
countries in culture, economy, entertainment, and technology. South Korea has been known as the country that often finds the difficulty while learning English, especially for speaking. Koreans have a strong accent while talking and the differences of using word by word are also caused why do Koreans have difficulty learning to speak in English. As what like the difficulties that are often found by Indonesian, most Koreans are not that confident to speak English due to focus on grammar and pronunciation.

Russia is one of the EFL countries in Europe which is located in East Europe and North Asia. English may be a popular language to be communicated and learned all over the world, but probably it does not happen in Russia. Living in Russia without can speak English is not a big deal because almost all of the things, starting from movies, books, etc are already translated into the Russian language. The importance of English is considered to be learned only when Russian goes to abroad.

Poland is a country which is located in central Europe and becomes a unique country that has many histories. English starts to become a common language for young learners in Poland. But, sadly that does not happen to elder people who even cannot speak English. Polish has a strong accent as well like all non-native speakers as usual. Therefore, sometimes the factors of difficulties in speaking English should be identified more.

Based on the considerations above, the writer dedicated to make the comparison of ELT from each country to increase students' speaking ability. The writer used the compilation of journals which showed the comparison of how four countries concerned about ELT in speaking for students' ability.

\section{RESEARCH METHODOLOGY}

$\mathrm{T}$ he method that is used in this research is a systematic review in the qualitative method according to the previous researches within ELT in educational journals. Therefore, the writers will only make a comparison which is already concluded based on the data of speaking ELT in Indonesia, South Korea, Russia, and Poland.

In the data collection, most of information and data that the writers got are about how ELT goes in each country and what are the differences, difficulties, and solution to make ELT in speaking ability can be a problem solving for all EFL countries in the world, not only limited to four countries above. But, we tried to highlight those four countries as the representative of each continent among Asia and Europe. In collecting the data, the writers used the compilation of educational journals contains how ELT of speaking goes, moreover in four countries, such as Indonesia, South Korea, Russia, and Poland.

\section{FINDING AND DISCUSSION}

\section{T ndonesia}

As one of the EFL countries in the world, we realize that there are not many people who communicate by using English in day-to-day. Even though more Indonesians use English in their daily life, many consider that English instruction is a failure in this country. One of the reasons for the failure is that there has been no unified national system of 
English education and, therefore, improvements of English communicative ability are painstakingly made.

This reason gave a challenge for the country to maintain and develop educational quality to increase the level of human skill. Bambang \& Cahyono (2006) stated that the need for English ability in the fifties and sixties was limited to academic purposes at the university level. Today, individuals need English to communicate with others at international forums. Accordingly, efforts need to be continuously made concerning quality improvements of English instruction in Indonesia. In the last quarter of the century, the teaching of EFL speaking in Indonesia has been closely connected to the concept of communicative competence which is emphasized within the Communicative Language Teaching (CLT) approach. (Bambang \& Cahyono, 2006).

Mukminatien (1999) found that students of English departments have a great number of errors when speaking. Those errors include of pronunciation (e.g., word stress and intonation), grammatical accuracy (e.g., tenses, preposition, and sentence construction), vocabulary (e.g., incorrect word choice), fluency (e.g., frequent repair), and interactive communication (i.e., difficulties in getting the meaning across or keeping the conversation going). The focus on EFL speaking can be centered on speaking accurately, for example like grammatical structure and pronunciation. Therefore, those things can help to encourage students' speaking ability in better ways. Many ways and methods can be applied, but mostly roleplay is one of the most popular ways to do. Another way like dialogue, small group discussion can be also popular methods that are usually done by the teacher in the class.

When we try to bring the EFL approach in ELT in Indonesia, interested readers can consult the exhaustive discussions (Jenkins, 2006; McKay, 2003; Seidlhofer, 2004).In the ELF view, speakers of ELF are not expected to produce utterances as similar as possible to the native speakers', but rather utterances that do not deviate too far from the utterances of the native speakers (Kirkpatrick, 2007).

As one of the important things to be focused on communication, speaking has to be a special thing to be learned to reach the goals of learning English since it is a tool for communication. Since we know that, there has been no unified national system concerning the development of oral proficiency moreover in the English instruction, future programs and research should be directed toward providing guidance to develop the speakers competent of English, involving considerations of components.

\section{South Korea}

English as an international language has been seen as an uncommon language in South Korea since it is seldom to be talked there. Despite how difficult is English in South Korea, but the existence of English still appears and implements when at the university entrance. Many students wish to be a student in top university in South Korea, but they must acquire a good command of English so that they can follow the soaring proportion of English mediated lectures 
at their respectively chosen top-notch universities.

If we take an example of South Korean university entrance requirements, either based on students' (Collegiate Scholastic Ability Test) CSAT scores or based on a set of criteria determined uniquely by each university. According to Jambor(2011), in South Korea, the elite SKY universities (Seoul National, Korea and Yonsei Universities) offer a significant number of their undergraduate courses in English (Korea at 34\%; SNU at 15; Yonsei at 28.5\% with a plan to increase to $35 \%$ ). Pohang University of Science and Technology (POSTEDH - the highest-ranked Korean university according to Times Higher Education - Reuters 2010 World Ranking) and the Korea Institute of Science and Technology are currently offering $80 \%$ and $85 \%$ of their undergraduate courses in English respectively, with both universities planning to increase the ratios of all undergraduate courses taught in English to $100 \%$ across the board, in the upcoming years.

Consequently, for any Korean student dreaming of studying at one of the SKY universities, POSTECH or KAIST, the basic requirement is his/her unfaltering dedication in pursuing a better than general competence in Academic English. Fundamentally, a significant number of the students. Therefore, based on the data that we can see if mostly Korean students focus only on grammatical structure and theoretical. When we talk about ELT in Korea, there are approaches and strategies used by the learners. O'Malley \& Chamot (1990) argued that more effective learners are those who use a greater variety of strategies and also use them in ways appropriate to the language-learning task. And, less effective learners not only have fewer strategy types but also frequently use strategies that are inappropriate to the task.Rogers in Alemi \& Daftarifard (2010) has named 'strategopedia'. He defines this term as "teaching learners the strategies they need so that they can learn on their own" (p. 3) has referred to it as one of ten scenarios that shape the teaching of second languages in the third millennium.ELT in Korea has been going, and not as inconsistencies and signs of major problems.

Shin in Taie (2015)found that not only teachers but also students did not consider being NS as the best teacher qualification. She referred to a mismatch between ELT beliefs held by different groups especially between teachers and students' and those of government as part of the reform's ideological problems. Shin in Taie (2015) tried to solve the controversies of ELT in Korea. According to Heredia \& Altarriba (2001), there is a constant relationship between globalization and localization, i.e., "globalization ... increasingly involves the creation and the incorporation of locality, processes which themselves largely shape, in turn, the compression of the world as a whole" (p. 40).

\section{Russia}

The existence of English in Russia is kind of similar to South Korea. Formal education like university still needs English as a requirement to get entrance. Even though in daily life, English is not something common in Russia, like 
everyone must speak Russian as well. As what Rasskazova, Guzikova, \& Green (2017) stated that to evaluate the average English language proficiency level among bachelor degree students in UrFU, the administration decided to attract an external authoritative body in the sphere of English language proficiency testing, Cambridge English Language Assessment, who conducted an in-depth study: testing about 1000 bachelor degree students, 100 English language teachers, doing classroom observation, talking to University decision-makers.

The data also showed that the students only learned English for the first two years of their four years program. This meant that they study English in class for a maximum of $216 \mathrm{~h}$, spread over two years of study. Additionally, the innovations for Russian universities make new demands on teachers, also changing what is expected of them in the classroom. Teacher training is seen to be essential and important for the success of the new curriculum and there has been an investment in professional development. This is intended to foster a move away from grammar-translation pedagogy in teacher-centered classrooms towards communicative language teaching in a learner-centered environment. To develop the students' communicative skills, it was suggested that there would need to be some fundamental changes moreover in the teachers' classroom practices. Specific issues that are stated by Rasskazova, Guzikova, \& Green (2017) are :

1. In class, students were mainly listening to the teacher and not interacting with each other; The ratio of teacher talk to student talk was very high;

2. Students were seated apart from each other in rows facing the teacher, limiting opportunities for peer-topeer interaction;

3. Teachers tended to focus on the more active learners, overlooking the more reticent members of the class;

4. Some teachers were more conscientious than others in setting self-study tasks while in some cases, learners had not completed the selfstudy tasks set;

5. In almost all lessons, teachers used overt on-the-spot oral correction techniques exclusively.

\section{Poland}

As one of the EFL countries that speak English better than other countries, Poland must have a specific strategy and approach to develop students' abilities in English, moreover speaking focus. Poland becomes an increasingly popular place for English teachers in Europe. Poland is a great country for English teachers to make their home: It is affordable, it is safe, and it offers an excellent work-life balance. According to Henderson \& Jarosz (2014), a communicative approach is usually the dominant paradigm in foreign language textbooks and teaching materials in European education systems. Despite it showed how important is the textbook for the students in around Europe, but it is also meaning that speaking approach or communication by using English should get focus as much as other English skills like reading, listening, and writing.

Learning about speaking in secondary schools in Europe mostly use 
textbooks as the popular media. It also teaches about how to speak, as one could also reasonably expect pronunciation to be a primary focus of textbooks in school, teaching materials and all of the classroom activities. Unfortunately, for a variety of reasons pronunciation teaching. Textbooks could help solve the problem, as they have the potential to guide teachers in effective pronunciation teaching: "Because many ESL instructors have limited training and confidence in teaching pronunciation, it falls to general-skills textbooks to ensure that pronunciation is addressed in L2 classrooms" (Derwing, Diepenbroek, \& Foote, 2012).

Henderson \& Jarosz (2014) stated European school textbooks may or may not be designed for the local context by publishers but they tend to be allinclusive general course books in which publishers take into account the national curriculum; for example, in Poland British publishers regularly invite Polish authors to contribute their expertise to textbook series. The questions were coming up based on the statement that showed if textbooks could help European students, moreover Polish and French students to increase their speaking ability. But, Henderson \& Jarosz (2014) hypothesized that textbooks are not providing structured, communicative materials concerning pronunciation and that what pronunciation work there tends to focus on segmental features. Results are discussed concerning contrastive analysis, common claims about learners' potential difficulties, the Lingua Franca Core, and relative functional load, to partially assess the appropriateness of features dealt with in textbooks. This data is aimed at how English pronunciation was treated in a sample of secondary school textbooks in France and Poland, with the hope of finding a variety of exercises leading toward communicative language practice (Henderson \& Jarosz, 2014).

\section{CONCLUSION}

$\mathrm{B}$ ased on the finding and discussion above, we could conclude that every single country has its different aim to learn English. Mostly, learning English is not aimed at usual communication in EFL countries since they have their mother language. Learning English is mostly aimed for educational purposes only, like as one of the requirements for entrance top universities or also to get a better job in a good way. The technique of teaching in each country also has differences. All those things are influenced by the problems and difficulties that can found in that area of the country. Therefore, we can see that the strategy and approach that are used by the teachers or government in the curriculum system will be determined the quality of English ability, moreover for speaking skills. There is no perfect method to be taught in ELT of speaking. All those methods have their strength and weakness. Therefore, after we tried to make the compilation of ELT of speaking from all over countries, hoping that people can take advantage and create an innovation to make it becomes easier for people to learn and teach English.

\section{REFERENCES}

Alemi, M., \& Daftarifard, P. (2010). Pedagogical Innovations in 
Language Teaching Methodologies. Journal of Language Teaching and Research, $1(6)$. https://doi.org/10.4304/jltr.1.6.765 $-770$

Bambang, U. W., \& Cahyono, Y. (2006). The Teaching of EFL Speaking in the Indonesian Context: The State of the Art. Bahasa dan Seni, 34(2), 269$292 . \quad$ Retrieved from http://sastra.um.ac.id

Brown, H. D. (2004). Language Assessment Principles and Classroom Practices. San Fransisco: Longman.

Derwing, T. M., Diepenbroek, L. G., \& Foote, J. A. (2012). How Well do General-Skills ESL Textbooks Address Pronunciation? TESL Canada Journal, 30(1), 22-44. Retrieved from https://files.eric.ed.gov/fulltext/EJ1 001889.pdf

Hadi, M. S., \& Izzah, L. (2019). Problem Based Learning (PBL) in Teaching English for Students of Primary School Teacher Education Department. English Language in Focus (ELIF), 1(1), 45-54. Retrieved from

https://jurnal.umj.ac.id/index.php/ ELIF/article/view/4501/3194

Harmer, J. (2015). The Practice of English Language Teaching. London: Pearson Education.

Henderson, A., \& Jarosz, A. (2014). Desperately Seeking a Communicative Approach: English Pronunciation in a Sample of French and Polish Secondary School Textbooks. Research in Language, 12(3), 261-278. https://doi.org/10.2478/rela-2014$0015 \ddot{~}$

Heredia, R. R., \& Altarriba, J. (2001). Bilingual Language Mixing: Why Do
Bilinguals Code-Switch? Current Directions in Psychological Science, 10(5), 164-168. https://doi.org/10.1111/14678721.00140

Jambor, P. Z. (2011). English Language Necessity: What it means for Korea and non-English speaking countries. Online Submission. Retrieved from https://eric.ed.gov/?id=ED528279

Jenkins, J. (2006). Current Perspectives on Teaching World Englishes and English as a Lingua Franca. TESOL Quarterly, $\quad 40(1), \quad 157$. https://doi.org/10.2307/40264515

Kayi, H. (2006). Teaching Speaking: Activities to Promote Speaking in a Second Language (TESL/TEFL). The Internet TESL Journal, 12(11). Retrieved from http://iteslj.org/Techniques/KayiTeachingSpeaking.html

Kirkpatrick, A. (2007). World Englishes: Implications for International Communication and English Language Teaching. Cambridge: Cambridge University Press.

McKay, S. L. (2003). Teaching English as an International Language: Rethinking Goals and Perspectives. The Electronic Journal for English as a Second Language, 7(1). Retrieved from http://www.teslej.org/wordpress/issues/volume7/ ej25/ej25r5/

O'Malley, J. M., \& Chamot, A. U. (1990). Learning Strategies in Second Language Acquisition. Learning Strategies in Second Language Acquisition. Cambridge University Press.

https://doi.org/10.1017/cbo97811 39524490

Qureshi, I. A. (2012). The Importance of Speaking Skills for EFL Learners. 
Retrieved from

https://upload.wikimedia.org/wikip edia/commons/e/e3/Speaking_Skill s.pdf

Rasskazova, T., Guzikova, M., \& Green, A. (2017). English Language Teacher Development in a Russian University: Context, Problems and Implications. Ampersand, 4, 1-9. https://doi.org/10.1016/j.amper.20 17.01.001

Richards, J. C. (2008). Teaching Listening and Speaking: From Theory to Practice. New York: Cambridge University Press.

Rizqiningsih, S., \& Hadi, M. S. (2019). Multiple Intelligences (MI) on Developing Speaking Skills. English Language in Focus (ELIF), 1(2), 127-
136. Retrieved from https://jurnal.umj.ac.id/index.php/ ELIF/article/view/4521/3206

Seidlhofer, B. (2004). Research Perspectives on Teaching English as a Lingua Franca. Annual Review of Applied Linguistics, 24, 209-239. https://doi.org/10.1017/s0267190 504000145

Taie, M. (2015). English Language Teaching in South Korea: A Route to Success? Theory and Practice in Language Studies, 5(1), 139. https://doi.org/10.17507/tpls.0501 .19

Ur, P. (1996). A course in English Language Teaching. Cambridge: Cambridge University Press. 